\title{
Dietary Fiber and $\beta$-glucan Contents of Oat Tarhana: A Turkish Fermented Cereal Food
}

\author{
Asli Yukselci Kilci ${ }^{1} \&$ Duygu Gocmen ${ }^{1}$ \\ ${ }^{1}$ Department of Food Engineering, Faculty of Agriculture Uludag University, Bursa, Turkey \\ Correspondence: Duygu Gocmen, Department of Food Engineering, Faculty of Agriculture, Uludag University, \\ 16059, Gorukle - Bursa, Turkey. E-mail: gocmend@gmail.com
}

Received: July 10, 2012 Accepted: July 27, 2012 Online Published: October 12, 2012

doi:10.5539/jas.v4n11p72 URL: http://dx.doi.org/10.5539/jas.v4n11p72

\begin{abstract}
Tarhana is a traditional Turkish fermented cereal based food, made from wheat flour, bakers' yeast, yogurt and different vegetables. After fermentation, the tarhana dough is dried and milled. Tarhana powder is most often used in the form of soup. In this study, oat flour (OF) and steel cut oat (SCO) were used to replace wheat flour in the tarhana formulation (control) at the levels of 10, 20, 30 and $40 \%(\mathrm{w} / \mathrm{w})$. Tarhana with $40 \%$ SCO had the highest insoluble dietary fiber (IDF), soluble dietary fiber (SDF) and total dietary fiber (TDF) values, followed by tarhana with 30 and $20 \%$ SCO. Control had the lowest $\beta$-glucan content $(0.13 \%)$ while tarhana with $40 \%$ SCO had the highest value $(1.50 \%)$. As the levels of OF and SCO increased in formulations, $\beta$-glucan contents increased. Results showed that OF and SCO additions improved the nutritional quality of tarhana by causing significant increases in dietary fiber and $\beta$-glucan contents. All of the soups with oat products and control were comparable in terms of the sensory properties. Overall, acceptances of soups were found the best at the sample with $10 \%$ OF. It can be concluded that usage of OF and SCO in tarhana did not give negative results in terms of acceptability.
\end{abstract}

Keywords: oat, dietary fiber, $\beta$-glucan, sensory evaluation, tarhana

\section{Introduction}

Tarhana is a traditional Turkish fermented cereal food. Since it is a fermented food made from cereal flours, yogurt and different vegetables and is a good source of B vitamins, minerals, organic acids and free amino acids. It is healthy for children, the elderly and patients (Daglioglu, 2000). It is highly flavored and thick-creamy and it can be easily digested (Ozdemir et al., 2007). After all ingredients are mixed and homogenized and dough is obtained. It is fermented at $30-35^{\circ} \mathrm{C}$ for $1-5$ days (Temiz and Pirkul, 1990; Temiz and Pirkul, 1991; Gocmen et al., 2004), then dried (Tarakci et al., 2004). Fermentation is usually carried out by using yogurt bacteria, Lactobacillus bulgaricus and Streptococcus thermophilus and bakers' yeast (Saccharomyces cerevisiae) (Ekinci, 2005). Both Lactic acid bacteria (LAB) and yeast fermentation occur simultaneously during tarhana production (Gocmen et al., 2004). Most of the tarhana consumed in Turkey is homemade and therefore sun-dried. However, there is a great commercial potential for the production of tarhana on an industrial scale using modern drying techniques (Tarakci et al., 2004; Ekinci, 2005). Tarhana powder is obtained by grinding of dried tarhana. It is mainly used to make a thick and creamy soup (Bilgicli et al., 2005). Tarhana powder is first mixed with cold water (1:5) and then let to dissolve for about half an hour, and finally cooked for 20 minutes with occasionally stirring. As soon as it boils some butter is added and resulting soup consumed at $70^{\circ} \mathrm{C}$. Cheese and roasted bread pieces can also be added upon request (Ozdemir et al., 2007).

Oat usage in human foods has increased as information on oats' beneficial nutritional properties has come to light. The authorization of the heart health claim for oats in the United States by the, The US Food and Drug Administration (FDA) is especially significant (Webster, 2002). Oat is useful for the control of diabetes, lipid profile (Butt et al., 2008), total and low density lipoprotein (LDL) cholesterol levels (Kestin et al., 1990). Oat grain contains high amounts of non-starch polysaccharides (Lasztity, 1999; Webster, 2002). These are extremely important group of "carbohydrates" (Webster, 2002) and the main constituents of dietary fiber (Lasztity, 1999). Dietary fiber (DF) is typically reported as total dietary fiber (TDF), soluble dietary fiber (SDF), and insoluble dietary fiber (IDF). DF plays an extremely important role in the nutritional benefits of "whole-grain products" especially oats, which were granted a heart health claim under the guidelines put forth in the Nutrition Labeling 
and Education Act of 1990 (Webster, 2002). The soluble fiber from oatmeal and oat bran is very effective to lower blood cholesterol and normalize blood sugar levels (Wood, 1991; Wood, 1993; Kahlon \& Chow, 1997; Butt et al., 2008). $\beta$-glucan is the major soluble fiber in oats. Estimates of the amount of $\beta$-glucan in SDF are $90 \%$. $\beta$-glucan and other soluble fibers are noted for their hypocholesterolemic effects and ability to slow the rate of nutrient absorption and retard the rate of gastric emptying (Webster, 2002). These nutritional and functional benefits attributed to $\beta$-glucan have recently greatly increased interest in oat as a human food (McMullen, 2000). Oatmeal or oat flour is a major constituent in granola bars, South American beverage products, and pancake mixes. Additionally, oatmeal is used as a thickening agent in soups, and gravies and as a meat extender (Webster, 2002).

The objective of this study was to investigate the effects of two different types of oat product (oat flour and steel cut oats) on dietary fiber and $\beta$-glucan contents of tarhana.

\section{Method}

\subsection{Materials}

To produce tarhana, wheat flour (Triticum aestivum) (Type 650), containing 13.3\% protein (db), $0.64 \%$ ash (db) and $13.4 \%$ moisture, was used and supplied from the Toru Flour Milling Co., Ltd (Bandirma / Turkey). Commercial pressed baker's yeast (Pakmaya, Izmit, Turkey) (Saccharomyces cerevisiae) with 70\% moisture content, salt $(\mathrm{NaCl})$, dried onion, tomato and paprika pastes were purchased from local markets in Bursa, Turkey. Stabilized oat meal (inactivated fat hydrolyzing enzymes) was obtained from Eti Food Co., Ltd. (Bozuyuk, Bilecik, Turkey). Oat meal was ground in a hammer mill (Falling Number-3100 Laboratory Mill, Perten Instruments $\mathrm{AB}$, Huddinge, Sweden) and sieved through $212 \mu \mathrm{m}$ sieve. The material (oat flour-OF) passing through the sieve was used. Steel cut oats (SCO) were also obtained from Eti Food Co., Ltd. (Bozuyuk, Bilecik, Turkey). These were whole oat grain that had been cut into small pieces. The OF and SCO were kept in refrigerator prior to before analyses or until analyzed.

\subsection{Production of Tarhana}

To prepare tarhana samples, flour $(100 \%)$, yogurt $50 \%$ (w/w, flour base), dried onion $2.5 \%$ (w/w, flour base), tomato paste $2.5 \%(\mathrm{w} / \mathrm{w}$, flour base), paprika paste $7.5 \%(\mathrm{w} / \mathrm{w}$, flour base), salt $(\mathrm{NaCl}) 7.5 \%(\mathrm{w} / \mathrm{w}$, flour base), and baker's yeast $2 \%$ (w/w, flour base) were used. For supplemented tarhana samples OF and SCO were used to replace wheat flour at the levels of 10, 20, 30 and 40\% (w/w). Control samples included no OF and SCO. The ingredients were mixed in a mixer (Electrolux Ditomix 5, GA, USA) for $5 \mathrm{~min}$. and dough samples were fermented at $30^{\circ} \mathrm{C}$ in a fermentation cabinet (Efe Co. Ltd., İzmir/Turkey) for 3 days. The fermented dough samples were dried at $50 \pm 2{ }^{\circ} \mathrm{C}$ in an air-convection oven (Efe Co. Ltd., İzmir/Turkey) to $9-10 \%$ moisture content. After drying, tarhana samples were ground into a rough powder by a hammer mill equipped with a 1-mm opening screen. The resulting powders were stored in a glass jar $(0.5 \mathrm{~L})$ at room temperature until analyzed.

\subsection{Analytical Methods}

The AACC methods were used for the determination of moisture (method 44-15.02), protein (method 46-10.01), ash (method 08-01.01) and dietary fiber (method 32-21.01) contents (AACC, 1999). The $\beta$-glucan levels were enzymatically determined by using AACC Method 32-23.01 (AACC, 1999), with the application of a mixed $\beta$-glucan linkage kit (Megazyme Int. Ireland Ltd., Wicklow, Ireland). Total acidity was determined by titration using $0.1 \mathrm{~N} \mathrm{NaOH}$ and expressed as percent lactic acid (Ibanoglu et al., 1999).

\subsection{Sensory Analysis}

The sensory evaluation of tarhana soup was determined by an untrained consumer panel with 22 panelists to determine color, taste, odor, mouth feel and overall acceptability. A 9-point hedonic scale with 9-like extremely, 8-like very much, 7-like moderately, 6-like slightly, 5-neither like or dislike, 4-dislike slightly, 3-dislike moderately, 2-dislike very much, and 1-dislike extremely was used. For each sample, $100 \mathrm{~g}$ dried tarhana powder (dry weight basis) was mixed with $1000 \mathrm{~mL}$ water. All samples were brought to a boil, $10 \mathrm{~g}$ of unsalted butter was added to each, and then they were allowed to simmer for $10 \mathrm{~min}$ over medium heat with constant stirring. The cooked samples were served to the panelists at a temperature of $70 \pm 2{ }^{\circ} \mathrm{C}$ (Gocmen et al., 2004). Water and bread were used to clear the palate before the each test sample. The samples were identified and coded by three-digit random numbers and served to the panelists in random order to guard against any bias.

\subsection{Statistical Analysis}

JMP software version 7.0.0 (SAS Institute Inc, Cary, North Carolina, USA) was used to perform the statistical analyses. When significant differences were found $(p<0.05)$, the Least Significant Difference (LSD) test was 
used to determine the differences among means.

\section{Results}

\subsection{Chemical Properties of Raw Materials}

The commercial wheat flour used in this study consisted of $13.4 \%$ moisture, $13.3 \%$ protein, and $0.64 \%$ ash. Ash contents of OF and SCO measured in the present study were $0.91 \%$ and $0.82 \%$, respectively. The protein contents of the OF and SCO were $10.63 \%$ and $9.65 \%$, respectively.

Table 1. Chemical compositions of raw materials ${ }^{1}$

\begin{tabular}{cccc}
\hline Raw Materials & Moisture (\%) & Ash* $\left.^{*} \%\right)$ & Protein* $\left.^{*} \%\right)$ \\
\hline Type 650 Wheat Flour & $13.4^{\mathrm{a}}$ & $0.64^{\mathrm{b}}$ & $13.3^{\mathrm{a}}$ \\
OF & $11.2^{\mathrm{b}}$ & $0.91^{\mathrm{a}}$ & $10.63^{\mathrm{b}}$ \\
SCO & $10.1^{\mathrm{b}}$ & $0.82^{\mathrm{a}}$ & $9.65^{\mathrm{b}}$
\end{tabular}

Means of samples followed by the same letter within the same column are not significantly differences $(p$ $<0.05$ ).

* dry weight basis.

\subsection{Dietary Fiber and $\beta$-glucan Contents of Raw Materials}

The content of insoluble dietary fiber (IDF), soluble dietary fiber (SDF) and total dietary fiber (TDF) in wheat flour, OF and SCO are presented in Table 2. Dietary fiber contents of OF and SCO were significantly $(p<0.05)$ higher than that of the wheat flour. The highest IDF and TDF contents were found in SCO (6.91 and 10.88\%, respectively) followed by OF ( 4.88 and $7.20 \%$, respectively) and wheat flour (2.05 and $2.69 \%$, respectively). The dietary fiber values of OF and SCO used in this study are lower than recorded by Silva and Ciocca (2005). One possible explanation for this is a difference in oat cultivars as well as climatic and geographical conditions. $\beta$-glucan of OF and SCO were also significantly higher than that of the wheat flour $(p<0.05)$. SCO had the highest $\beta$-glucan content (3.33\%) and wheat flour had the lowest value $(0.11 \%)$.

Table 2. Dietary fiber and $\beta$-glucan contents of raw materials ${ }^{1}$

\begin{tabular}{ccccc}
\hline & IDF (\%) & SDF (\%) & TDF $(\%)$ & $\beta$-glucan $(\%)$ \\
\hline Type 650 Wheat Flour & $2.05^{\mathrm{c}}$ & $0.64^{\mathrm{b}}$ & $2.69^{\mathrm{c}}$ & $0.11^{\mathrm{c}}$ \\
OF & $4.88^{\mathrm{b}}$ & $0.91^{\mathrm{a}}$ & $7.20^{\mathrm{b}}$ & $1.85^{\mathrm{b}}$ \\
SCO & $6.91^{\mathrm{a}}$ & $0.82^{\mathrm{a}}$ & $10.88^{\mathrm{a}}$ & $3.33^{\mathrm{a}}$
\end{tabular}

Means of samples followed by the same letter within the same column are not significantly differences $(p$ $<0.05)$.

\subsection{Chemical Characteristics of Tarhana Samples}

Chemical properties of tarhana samples are given in Table 3. The ash contents of tarhana samples supplemented with OF and SCO were between $1.98 \%$ and $2.44 \%$. OF and SCO additions significantly $(p<0.05)$ increased the ash contents of tarhana samples. Control had the highest protein $(13.91 \%)$ contents. Oat addition significantly $(p<0.05)$ decreased the protein contents of tarhana samples due to the fact that protein contents of OF and SCO used in this study had lower levels than that of the wheat flour. As the addition levels of OF and SCO were increased, there were a significantly $(p<0.05)$ increase in total acidity of tarhana samples. Control had the lowest acidity $(1.02 \%)$ value while the $40 \%$ OF and SCO tarhana had the highest acidity $(1.20 \%$ and $1.23 \%$, respectively) values. 
Table 3. Chemical compositions of tarhana samples ${ }^{1}$

\begin{tabular}{cccccc}
\hline & OF (\%) & Moisture(\%) & Ash*(\%) & Protein*(\%) & Acidity(\%) \\
\hline Control & 0 & $9.33^{\mathrm{e}}$ & $1.74^{\mathrm{e}}$ & $13.91^{\mathrm{a}}$ & $1.02^{\mathrm{b}}$ \\
OF & 10 & $9.37^{\mathrm{de}}$ & $1.98^{\mathrm{d}}$ & $13.84^{\mathrm{a}}$ & $1.05^{\mathrm{ab}}$ \\
& 20 & $9.43^{\mathrm{bcde}}$ & $2.10^{\mathrm{cd}}$ & $13.46^{\mathrm{bc}}$ & $1.11^{\mathrm{ab}}$ \\
& 30 & $9.49^{\mathrm{abc}}$ & $2.23^{\mathrm{bc}}$ & $13.44^{\mathrm{c}}$ & $1.14^{\mathrm{ab}}$ \\
& 40 & $9.55^{\mathrm{a}}$ & $2.34^{\mathrm{ab}}$ & $13.42^{\mathrm{c}}$ & $1.20^{\mathrm{ab}}$ \\
SCO & 10 & $9.39^{\text {cde }}$ & $2.19^{\mathrm{bc}}$ & $13.57^{\mathrm{b}}$ & $1.08^{\mathrm{ab}}$ \\
& 20 & $9.45^{\mathrm{abcd}}$ & $2.31^{\mathrm{ab}}$ & $13.40^{\mathrm{c}}$ & $1.14^{\mathrm{ab}}$ \\
& 30 & $9.49^{\mathrm{abc}}$ & $2.39^{\mathrm{a}}$ & $13.39^{\mathrm{c}}$ & $1.17^{\mathrm{ab}}$ \\
& 40 & $9.51^{\mathrm{ab}}$ & $2.44^{\mathrm{a}}$ & $13.35^{\mathrm{c}}$ & $1.23^{\mathrm{a}}$
\end{tabular}

Means of samples followed by the same letter within the same column are not significantly differences $(p<0.05)$

*dry weight basis.

\subsection{Dietary Fiber and $\beta$ - glucan Contents of Tarhana Samples}

There were significant $(p<0.05)$ increases in dietary fiber contents of the samples supplemented with OF and SCO compared to that of control (Table 4). IDF contents of tarhana samples with OF and SCO ranged from $2.13-3.25 \%$, SDF values of those samples varied from $1.30-1.95 \%$ and TDF ranged from $3.43-5.20 \%$. The highest IDF, SDF and TDF contents were found in the sample with $40 \%$ SCO $(3.25,1.95$ and $5.20 \%$, respectively). This could be explained because the original dietary fiber content of OF and SCO was higher than that of the wheat flour. Oat grain contains high amounts of non-starch polysaccharides and these are the main constituents of dietary fiber (Lasztity, 1999; Webster, 2002). Our results were in agreement with previous report (Tamime et al., 2000).

Table 4. Dietary fiber and $\beta$-glucan contents of tarhana samples ${ }^{1}$

\begin{tabular}{cccccc}
\hline & OF (\%) & IDF (\%) & SDF (\%) & TDF (\%) & $\beta$-glucan (\%) \\
\hline Control & 0 & $1.35^{\mathrm{d}}$ & $0.25^{\mathrm{d}}$ & $1.60^{\mathrm{e}}$ & $0.13^{\mathrm{e}}$ \\
OF & 10 & $2.13^{\mathrm{c}}$ & $1.30^{\mathrm{c}}$ & $3.43^{\mathrm{d}}$ & $1.02^{\mathrm{d}}$ \\
& 20 & $2.25^{\mathrm{bc}}$ & $1.45^{\mathrm{bc}}$ & $3.70^{\mathrm{d}}$ & $1.10^{\mathrm{cd}}$ \\
& 30 & $2.28^{\mathrm{bc}}$ & $1.58^{\mathrm{bc}}$ & $3.86^{\mathrm{cd}}$ & $1.21^{\mathrm{bcd}}$ \\
& 40 & $2.51^{\mathrm{bc}}$ & $1.63^{\mathrm{abc}}$ & $4.14^{\mathrm{bc}}$ & $1.28^{\mathrm{abc}}$ \\
SCO & 10 & $2.10^{\mathrm{c}}$ & $1.50^{\mathrm{bc}}$ & $3.60 \mathrm{~d}$ & $1.21^{\mathrm{bcd}}$ \\
& 20 & $2.54^{\mathrm{bc}}$ & $1.63^{\mathrm{abc}}$ & $4.17^{\mathrm{bc}}$ & $1.31^{\mathrm{abc}}$ \\
& 30 & $2.65^{\mathrm{b}}$ & $1.79^{\mathrm{ab}}$ & $4.44^{\mathrm{b}}$ & $1.43^{\mathrm{ab}}$ \\
& 40 & $3.25^{\mathrm{a}}$ & $1.95^{\mathrm{a}}$ & $5.20^{\mathrm{a}}$ & $1.50^{\mathrm{a}}$
\end{tabular}

Means of samples followed by the same letter within the same column are not significantly differences $(p$ $<0.05)$.

$\beta$-glucan contents of tarhana samples with OF and SCO were in the range of $1.02-1.50 \%$ (Table 4). There were statistically significant $(p<0.05)$ differences between control and oat tarhana samples. Control sample had the lowest $\beta$-glucan content $(0.13 \%)$ while the tarhana with $40 \%$ SCO had the highest value $(1.50 \%)$. Oat groats contain significant amounts of $\beta$-glucan. FDA has permitted the use of a claim that oat soluble fiber has the ability to reduce the risk of heart disease. According to the FDA for health claims, the required dose of $\beta$-glucan for a single food is $0.75 \mathrm{~g} /$ serving (Butt et al., 2008). Therefore, these tarhana samples with OF and SCO can claim to be a good source of $\beta$-glucan. 


\subsection{Sensory Findings of Tarhana Samples}

The effects of OF and SCO on the sensorial properties of tarhana soups were not statistically significant (Table 5). All of the soups prepared with oat products and control soup were comparable in terms of the sensory properties. Except for two samples with $30 \%$ OF and $40 \%$ SCO, all oat tarhana soups had higher scores in overall acceptance than control sample. Overall acceptance of tarhana soups was found to be the best with the $10 \%$ OF. The results of sensorial analysis showed that supplementation of OF and SCO into tarhana did not give undesirable taste and odor. All tarhana soups prepared with OF and SCO were liked slightly by panelists.

Table 5. Sensorial properties of tarhana samples

\begin{tabular}{ccccccc}
\hline & $\begin{array}{c}\text { OF } \\
\text { (\%) }\end{array}$ & Color & Taste & Odour & Mouth Feel & $\begin{array}{c}\text { Overall } \\
\text { Acceptability }\end{array}$ \\
\hline Control & 0 & $6.05 \pm 1.46$ & $5.48 \pm 1.83$ & $5.57 \pm 1.60$ & $5.68 \pm 1.76$ & $5.59 \pm 1.74$ \\
OF & 10 & $6.00 \pm 1.90$ & $6.45 \pm 1.44$ & $6.14 \pm 1.52$ & $6.27 \pm 1.55$ & $6.48 \pm 1.12$ \\
& 20 & $5.73 \pm 1.64$ & $5.55 \pm 1.50$ & $5.36 \pm 129$ & $5.41 \pm 1.87$ & $5.71 \pm 1.49$ \\
& 30 & $5.33 \pm 1.93$ & $5.38 \pm 1.66$ & $5.30 \pm 1.56$ & $5.10 \pm 1.92$ & $5.45 \pm 1.57$ \\
& 40 & $6.48 \pm 0.98$ & $5.81 \pm 1.50$ & $5.62 \pm 1.32$ & $5.95 \pm 1.32$ & $5.75 \pm 1.52$ \\
SCO & 10 & $6.00 \pm 1.52$ & $6.29 \pm 1.55$ & $6.33 \pm 1.43$ & $6.00 \pm 1.70$ & $5.95 \pm 1.80$ \\
& 20 & $5.76 \pm 1.45$ & $5.57 \pm 1.50$ & $5.50 \pm 1.19$ & $5.59 \pm 1.56$ & $5.67 \pm 1.39$ \\
& 30 & $5.24 \pm 1.87$ & $5.45 \pm 2.28$ & $5.14 \pm 1.81$ & $5.95 \pm 1.65$ & $6.10 \pm 1.83$ \\
& 40 & $5.68 \pm 1.73$ & $5.41 \pm 1.29$ & $5.29 \pm 1.76$ & $5.32 \pm 2.15$ & $5.57 \pm 1.94$ \\
\hline
\end{tabular}

\section{Discussion}

Substitution of wheat flour in tarhana formulation with OF and SCO at 10, 20, 30 and 40\% levels positively affected the dietary fiber and $\beta$-glucan contents. According to the FDA, the required dose of $\beta$-glucan for a single food is $0.75 \mathrm{~g} /$ serving. Oat addition, especially SCO supplementation enhanced the nutritional value of the tarhana samples by increasing their $\beta$-glucan content beyond the $0.75 \mathrm{~g} / \mathrm{serving}$ required by the FDA for health claims. Therefore, these tarhana samples can claim to be a good source of $\beta$-glucan. The use of OF and SCO in tarhana formulations may have health benefits and effective for nutritional advantages. The results of sensory analysis also showed that supplementation of OF and SCO into tarhana resulted in acceptable soup properties.

\section{Acknowledgements}

The authors would like to thank the The Scientific and Technological Research Council of Turkey (TUBITAK) for financially supporting this research project (Project No: TOVAG 110 O 805).

\section{References}

AACC. (1999). Approved Methods of American Association of Cereal Chemists, St. Paul, MN, USA.

Bilgicli, N., Elgun, A., Herkan, E. N., Turker, S., Ertas, N., \& Ibanoglu, S. (2005). Effect of Wheat Germ / Bran Addition on the Chemical, Nutritional and Sensory Quality of Tarhana, A Fermented Wheat Flour - Yoghurt Product. J. of Food Eng., 77, 680-686. http://dx.doi.org/10.1016/j.jfoodeng.2005.07.030

Butt, M. S., Tahir-Nadeem, M., Khan, M. K. I., \& Shabir, R. (2008). Oat: unique among the cereals. Eur. J. Nutr., 47, 68-79. http://dx.doi.org/10.1007/s00394-008-0698-7

Daglioglu, O. (2000). Tarhana as a Traditional Turkish Fermented Cereal Food, Its Recipe, Production and Composition. $\quad$ Nahrung., $\quad$ 85-88. http://dx.doi.org/10.1002/(SICI)1521-3803(20000301)44:2<85::AID-FOOD85>3.0.CO;2-H

Ekinci, R. (2005). The Effect of Fermentation and Drying on the Water-Soluble Vitamin Content of Tarhana, a Traditional Turkish Cereal Food. Food Chem., 90, 127-132. http://dx.doi.org/10.1016/j.foodchem.2004.03.036

Gocmen, D., Gurbuz, O., Roussef, R. L., Smoot, J. M., \& Dagdelen, A. F. (2004). Gas Chromatographic Olfactometric Characterization Of Aroma Active Compounds In Sun - Dried And Vacuum - Dried Tarhana. 
Eur. Food Res. Tech., 218, 573-578. http://dx.doi.org/10.1007/s00217-004-0913-6

Ibanoglu, S., Ibanoglu, E., \& Ainsworth, P. (1999). Effect of Different Ingredients on the Fermentation Activity in Tarhana. Food Chem., 64, 103-106. http://dx.doi.org/10.1016/S0308-8146(98)00071-5

Kahlon, T. S., \& Chow, F. I. (1997). Hypocholesterolemic effects of oat, rice, and barley dietary fibers and fractions. Cereal Food World, 42, 86-92.

Kestin, M., Moss, R., Clifton, P. M., \& Nestel, P. J. (1990). Comparative effects of three cereal brans on plasma lipids, blood pressure and glucose metabolism in mildly hypercholesterolemic men. Am. J. Clin. Nutr., 52, 661-666.

Lasztity, R. (1999). The chemistry of oats. In: Cereal Chemistry. (published by Akademiai Kiado), 192-213. Budapest, Hungary.

McMullen, M. S. (2000). Oats. In: Handbook of Cereal Science and Technology (edited by C. Kulp, \& J. G. Ponte) (pp 127-148). New York: 270 Madison Avenue.

Ozdemir, S., Gocmen, D., \& Kumral, A. (2007). Tradıtınal Turkısh Fermented Cereal Food: Tarhana. Food Reviews Int., 23(2), 107-121. http://dx.doi.org/10.1080/87559120701224923

Silva, L. P., \& Ciocca, M. L. (2005). Total, insoluble and soluble dietary fiber values measured by enzymatic-gravimetric method in cereal grains. Journal of Food Composition and Analysis, 18, 113-120. http://dx.doi.org/10.1016/j.jfca.2003.12.005

Tamime, A. Y., Muir, D. D., Khaskheli, M., \& Barclay, M. N. I. (2000). Effect of Processing Conditions and Raw Materials on the Properties of Kishk 1. Compositional and Microbiological Qualities. Lebensmittel-Wissenschaft und-Technologie, 33, 444-451. http://dx.doi.org/10.1006/fstl.2000.0686

Tarakci, Z., Dogan, I. S., \& Koca, A. F. (2004). A Traditional Fermented Turkish Soup, Tarhana, Formulated with Corn Flour and Whey. Int. J. of Food Sci. and Techn., 39, 455-458. http://dx.doi.org/10.1111/j.1365-2621.2004.00803.x

Temiz, A., \& Pirkul, T. (1990). Chemical and Microbiological Changes in Tarhana Fermentation. Gida, 15(2), 119-126.

Temiz, A., \& Pirkul, T. (1991). Chemical and Sensorial Properties of Tarhana Samples Produced with Different Components. Gida, 16 (1), 7-13.

Webster, F. H. (2002). Whole-grain oats and oat product. In: Whole-Grain Foods in Health and Disease. L. Marquart, J. L. Slavın, R. G. Fulcher (eds.), 83-123. St. Paul, Minnesota, USA: American Asssociation of Cereal Chemists, Inc.

Wood, P. J. (1991). Oat $\beta$-glucan physicochemical properties and physiological effects. Trends Food Sci Tech., 2, 311-314. http://dx.doi.org/10.1016/0924-2244(91)90733-Y

Wood, P. J. (1993). Physicochemical characteristics and physiological properties of oat (1 fi 3) (1 fi 4)- $\beta$-D-glucan. In: Oat bran. P. J. Wood (ed.) (pp 49-82). St. Paul, Minnesota, USA: AACC Inc. 